\title{
Patients with Congenital Low-Flow Vascular Malformation Treated with Low Dose Sirolimus
}

\author{
Veroniek E. M. Harbers (1) - Gerard A. P. J. M. Rongen • \\ Carine J. M. van der Vleuten • Bas H. Verhoeven • Peter C. J. de Laat • \\ Chantal M. A. M. van der Horst - Willemijn M. Klein • \\ Leo J. Schultze Kool • D. Maroeska W. M. te Loo
}

Received: March 22, 2021 / Accepted: April 22, 2021 / Published online: May 18, 2021

(C) The Author(s) 2021

\section{ABSTRACT}

Introduction: Patients with congenital vascular malformations often suffer from an impaired quality of life (QoL) because of pain and functional disabilities. Previous studies have shown

Supplementary Information The online version contains supplementary material available at https:// doi.org/10.1007/s12325-021-01758-y.

V. E. M. Harbers $(\bowtie) \cdot$ L. J. Schultze Kool Department of Radiology and Nuclear Medicine, Radboud University Medical Center, Geert Grooteplein Zuid 22, 6525 GA Nijmegen, Gelderland, the Netherlands

e-mail: veroniek.harbers@radboudumc.nl

G. A. P. J. M. Rongen

Department of Internal Medicine and Pharmacology-Toxicology, Radboud University Medical Center, Geert Grooteplein Noord 21, 6525

EZ Nijmegen, Gelderland, the Netherlands

\section{J. M. van der Vleuten}

Department of Dermatology, Radboud University

Medical Center, Rene Descartesdreef 1, 6525 GL

Nijmegen, Gelderland, the Netherlands

\section{B. H. Verhoeven}

Department of Surgery, Radboud University Medical Center, Geert Grooteplein Zuid 10, 6525 GA

Nijmegen, Gelderland, the Netherlands

V. E. M. Harbers . C. J. M. van der Vleuten .

B. H. Verhoeven - W. M. Klein - L. J. Schultze Kool ·

D. M. W. M. t. Loo

HECOVAN Workgroup, Nijmegen, the Netherlands that the mTOR inhibitor sirolimus can reduce complaints and improve QoL in some patients. High target levels of sirolimus of $10-15 \mathrm{ng} / \mathrm{ml}$ were well tolerated; however, in a relative high percentage of patients sirolimus caused serious adverse events (AEs).

Methods: A case series of 12 patients with therapy-resistant low-flow vascular malformations was treated with sirolimus, using low target levels of $4-10 \mathrm{ng} / \mathrm{ml}$. Efficacy of sirolimus

\section{P. C. J. de Laat}

Department of Pediatric Oncology, WEVAR-Team, Rotterdam Erasmus MC-Sophia, Postbus 2040, 3000 CA Rotterdam, Zuid-Holland, the Netherlands

C. M. A. M. van der Horst

Department of Plastic Reconstructive and Hand Surgery, AVA-Team, Amsterdam University Medical Center, Noord-Holland, Meibergdreef 9, 1105 AZ Amsterdam, the Netherlands

W. M. Klein Department of Radiology and Nuclear Medicine, Radboud University Medical Center, Geert Grooteplein Zuid 10, 6525 GA Nijmegen, Gelderland, the Netherlands

D. M. W. M. t. Loo

Department of Pediatric Hematology, Radboud University Medical Center, Geert Grooteplein Zuid 10, 6525 GA Nijmegen, Gelderland, the Netherlands 
was evaluated in regard to pain symptoms using the visual analogue scale/numeric rating scale and patients reported QoL. To rule out a placebo effect of sirolimus, sirolimus was stopped after a certain time point and reintroduced as soon as complaints returned. Adverse events were closely monitored and graded using the Common Terminology Criteria for Adverse Events (CTCAE) grading.

Results: An improvement in symptoms was seen in $92 \%(n=11 / 12)$ of patients. In nine patients pain complaints returned. Seven out of nine of them (78\%) again experienced a reduction of symptoms after restarting sirolimus treatment. Despite low target levels, these response rates are comparable to those found in the literature using higher target levels of sirolimus. However, significantly less serious AEs were observed with low dose sirolimus, suggesting low dose sirolimus might be safer. Unfortunately, young adolescent female patients developed serious menstrual disturbances during treatment with low dose sirolimus. We describe this adverse event for the first time in patients with congenital vascular malformations and this might be specifically related to low dose sirolimus.

Conclusions: Low dose sirolimus showed a high efficacy in patients with therapy-resistant and low-flow malformation, with a lower incidence of serious adverse events. At the same time a new adverse event, namely menstrual cycle disturbance, was observed in young adolescents, indicating the need for caution when sirolimus is given. This is extremely relevant to patients with low-flow vascular malformation, who are likely to require lifelong treatment for their condition.

Keywords: Low dose sirolimus; Lymphatic malformation; mTOR inhibitor; Pain; Sirolimus; Vascular malformation; Venous malformation

\section{Key Summary Points}

Patients with congenital vascular malformations often suffer from an impaired quality of life because of pain and functional disabilities. Sirolimus is an effective treatment; however, it can lead to serious adverse events.

This case series aims to address whether low target sirolimus levels will result in a high efficacy in patients with therapyresistant low-flow malformations and will lead to a low incidence of serious adverse events?

An improvement in symptoms was seen in $85 \%$ of patients, a rate which is comparable to those found in the literature, and related to less serious adverse events. However, menstrual cycle disturbances were seen as a new observed adverse event.

This case series suggests that low dose sirolimus is a high efficacy and safe treatment of patients with vascular malformation. Future research is necessary to confirm this result, since lifelong treatment is likely required for patients with low-flow vascular malformation.

\section{DIGITAL FEATURES}

This article is published with digital features, including a summary slide, to facilitate understanding of the article. To view digital features for this article go to https://doi.org/10.6084/ m9.figshare.14464956.

\section{INTRODUCTION}

Vascular malformations include a heterogenous group of developmental anomalies of the vascular system: capillaries, veins, arteries, 
lymphatics, or any combination of these vessels may be involved. The International Society for the Study of Vascular Anomalies (ISSVA) classified vascular malformations into the following categories [1]: simple low-flow vascular malformation, i.e., capillary (CM), lymphatic (LM), venous (VM), and high flow vascular malformations, i.e., arteriovenous (AVM). Additionally, Klippel-Trénaunay syndrome (KTS) or CLOVES (congenital lipomatous overgrowth with vascular malformations, epidermal nevi, and scoliosis) syndrome are examples of combined, vascular malformation of major named vessels, and vascular malformation associated with other anomalies.

Vascular malformations are congenital but can be discovered at any life stage, depending on their size and associated symptoms. Unfortunately, treatment is challenging and because of the complexity of the vascular malformation it is not always successful, leaving patients with a high clinical burden and subsequently a reduced quality of life (QoL) [2]. Clinical symptoms that reduce the QoL in patients with low-flow vascular malformations include pain, functional impairment, bleeding, thrombophlebitis, ulceration, infections, and leakage (in LM) [3].

Current treatment options for low-flow vascular malformation are still generally conservative, with compression bandages, analgesics, anti-inflammatory, or anticoagulation drugs. The gold standard for treatment is invasive treatment with intralesional sclerotherapy or embolization sometimes in combination with surgery [4]. Interestingly, in the past 10 years there has been a clear shift due to increased availability of target molecular drug therapy. This target drug therapy is based on the genetic mutations which can be found in the vascular malformations. The majority of the somatic mutations found in low-flow vascular malformations are in genes present in the mTOR pathway, such as PIK3CA, and TEK/TIE-2 leading to a gain of function and increased activity of mTOR [5-9]. To date, the most frequently found genetic mutations are located in the phosphoinositide 3 kinase (PI3K)-protein kinase B (AKT)-mammalian target of rapamycin (mTOR) signaling pathway [5]. The activation of mTOR leads to regulation of angiogenesis, cell proliferation, and glucose metabolism. Therefore, the inhibition of this pathway in these patients seems a logical approach to treatment.

In cells, sirolimus binds to the immunophilin FK binding protein 12 (FKBP-12), which in turn inhibits the activation of mTOR. This inhibition results in the obstruction of several signal transduction pathways, thereby inhibiting downstream protein biosynthesis, cell proliferation, and angiogenesis $[10,11]$. In theory, this should decrease the size of the low-flow vascular malformation or at least inhibit activity and stop further growth. However, the mTOR inhibition also leads to inhibition of lymphocyte activation which results in immunosuppression and might therefore be associated with an increased susceptibility to infections [12].

Several studies have been performed to explore the use of sirolimus as a treatment option in low-flow vascular malformations [13-16]. In these trials and case series, sirolimus was administered to patients with low-flow vascular malformations who were refractory to standard treatments and experienced a reduced QoL due to pain and/or functional limitations. Patients were treated with rather high target sirolimus levels of $10-15 \mathrm{ng} / \mathrm{ml}$ leading to a partial response in $85-100 \%$ of patients [13-16]. Although these open-label trials have shown a significant reduction of pain in patients with venous and lymphatic malformations, many of these patients developed adverse events such as bone marrow toxicity and liver disturbances. Questions remain as to what the optimum dose of sirolimus might be and which blood levels of sirolimus correspond to the best therapeutic effect without causing serious adverse events. While there are studies in patients with vascular malformations describing that adverse events using sirolimus as a single agent are moderate and manageable, there are also case reports presented with fatal outcome or development of grade III and IV toxicities due to sirolimus $[12,17-20]$. As it is unknown which duration of treatment will be necessary, it might be prolonged for a longer time period. Immediately another question arises: what are the long-term 
effects of sirolimus treatment and will they disappear if sirolimus is discontinued?

In this case series, lower target levels (4-10 ng/ml) than previously described were retained on the basis of laboratory and clinical studies [21-23]. The main reason to prescribe low dosage of sirolimus was to prevent serious adverse events as described in previous studies, without hampering therapeutic efficacy [12, 14, 16, 19, 24-27]. Furthermore, patients presented here had a long follow-up time, giving the unique opportunity to evaluate longterm adverse events. In all patients sirolimus was withdrawn at a certain time point, offering the possibility to gain insight into the time window in which complaints might return and to evaluate whether adverse events observed were truly caused by sirolimus and reoccurred when sirolimus was restarted.

\section{THERAPEUTIC INTERVENTION WITH SIROLIMUS}

In total 12 patients were treated with low dose sirolimus between 2015 and 2021. All patients included in the case series had a severe form of therapeutic-resistant congenital vascular malformation, experiencing severe pain and/or impairments. The main goal of treatment was to reduce pain symptoms and functional impairments and in this way improve QoL. The results of the treatment were analyzed in a retrospective way.

The case series was approved as an nWMO study, i.e., not falling under the Medical Research Involving Human Subjects Act, by the research ethics committee (CMO Regio Arnhem-Nijmegen-institutional review board) in the Netherlands. The case series was performed in accordance with the Declaration of Helsinki and Good Clinical Practice guidelines. Informed consent was obtained in all patients before start. The illustrated patients and their parents gave their consent for publication and image use.

All patients were treated with low dose sirolimus with target levels ranging between 4 and $10 \mathrm{ng} / \mathrm{ml}$. Pharmacodynamics of low dose sirolimus in respect of efficacy and adverse events were noted during this case series.
Patients received sirolimus for 3-6 months depending on their response, after which sirolimus treatment stopped. If complaints (e.g., pain) did not reoccur, patients were followed for at least 1 year, during which time the duration of the pain/symptom-free period and any serious adverse events were measured. If pain or other symptoms related to the vascular malformation [e.g., increase of the size of vascular malformation, lymph leakages (lymphatic malformations)] returned, sirolimus treatment was restarted in case there was a good treatment response during the first treatment period.

Since sirolimus has immunosuppressive properties, co-trimoxazole was prescribed as a prophylaxis for Pneumocystis jiroveci pneumonia [28]. Recent guidelines suggest that this prophylaxis is not necessary, citing no clear evidence of increased infection; however, these guidelines were not available when treatment with sirolimus was started in these cases. Additionally, using low dose sirolimus may lead to a lower incidence of infections compared to higher doses. For this reason it is possibly not necessary to prescribe co-trimoxazole as prophylaxis. Adverse events were assessed according to the Common Terminology Criteria for Adverse Events (CTCAE version 4.03).

As patients were treated on the basis of intention to treat and no other treatment options were available; magnetic resonance imaging (MRI) was not compulsory before starting sirolimus. However, in some patients MRIs were obtained as part of the learning curve of the first patients treated with sirolimus. Evaluation of the effect of sirolimus on the size of the vascular malformation was therefore only possible in these patients.

Pain reduction was evaluated using the visual analogue scale (VAS score) in children and the numeric rating scale (NRS score) in adults in the whole time period (the first period, after stopping sirolimus and subsequently after restarting it). QoL was assessed on the basis of patient-reported outcomes. 


\section{RESULTS}

The study population consisted of 12 patients (aged between 1 and 50 years; eight male, four female). The clinical characteristics of the patients are shown in Table S1 in the supplementary material. All patients had an untreatable form of low-flow vascular malformation. The initial treatment duration with sirolimus was at least 3 months and 6 months maximum. Target plasma levels of sirolimus were between 4.0 and $10.0 \mathrm{ng} / \mathrm{ml}$ (mean target levels $5.8 \pm 2.21 \mathrm{ng} / \mathrm{ml})$. In total 11 patients experienced pain reduction of whom five became entirely pain free (pretreatment pain scores 6-10); only one patient (patient 4) experienced no change in symptoms. Pain reduction was achieved rapidly in most patients with a mean of 7 weeks' treatment. Table 1 summarizes the results per patient.

After the first treatment period, sirolimus was stopped to evaluate how long patients would be free of pain. Unfortunately, all patients developed pain/symptoms within 10 days to 4 months after stopping sirolimus. Nine of these patients restarted sirolimus treatment shortly after return of complaints (see Table S2 in the supplementary material).

Three patients did not restart sirolimus despite the positive response primarily observed. Reasons were a loss of energy (patient 6), prostatitis and logistic reasons (patient 12), or the initiation of a different mTOR inhibitor (everolimus) (patient 7). The last mentioned patient showed a significant reduction in complaints again, illustrating that inhibition of the mTOR pathway was effective. A substantial relationship between sirolimus and the amelioration of symptoms was confirmed during reinduction of sirolimus in seven patients. This indicates the efficacy of sirolimus in respect to pain reduction even when target levels of sirolimus are low. In eight out of 12 patients an MRI of the vascular malformation was performed after the first treatment period with sirolimus. In four of these eight patients, a size reduction of the low-flow vascular malformation was found. Stable disease was observed in the remaining four patients.
MRIs were also performed in six of the nine patients who restarted with sirolimus and were treated for an additional period of 1 year with sirolimus. One patient had stable disease and one patient had an increase of the size of the abdominal cysts present. Four patients showed a further decrease in size of the vascular malformations. In two of them, reduction of size of vascular malformation offered the opportunity to perform surgery and further reduce the size of the vascular malformation. Both cases (patients 5 and 10) are described in more detail below.

\section{CASE PRESENTATION}

\section{Case 1}

A young girl presented at the age of 9 years with complaints of severe pain of the left calf in the hospital (patient 5). It became clear that the pain was caused by a vascular malformation and the girl was referred to an expert center for vascular anomalies (HECOVAN, Nijmegen, the Netherlands). Biopsy showed a venous malformation. Sclerotherapy combined with surgery led first to a good effect; however, pain complaints returned quickly and the interventions thereafter did not have the desired effect. The girl was treated with supportive analgesic treatment by a specialized pain team; however, despite all medicines given, severe pain (VAS scores 6-8) remained. There was a significant reduction in QoL as reported by the patient; she could not walk for more than $5 \mathrm{~min}$ and was unable to cycle or do activities with her friends. At the age of 13, sirolimus (target levels $3.5-4.5 \mathrm{ng} / \mathrm{ml}$ ) was started. Within 2 weeks the girl was pain free (VAS score 0). Main adverse events were aphthous lesions. At that time point no menstrual problems were noticed. After 6 months of treatment, sirolimus was interrupted and an MRI was performed, showing a significant reduction of the vascular malformation (Fig. 1).

Unfortunately, within 2 weeks after stopping sirolimus, pain complaints returned. This time sirolimus was restarted for a longer time period and the patient was very quickly pain free again. 
Table 1 Summary of clinical and MRI responses in the first and second (rechallenge) periods

\begin{tabular}{|c|c|c|c|c|}
\hline \multirow{2}{*}{$\begin{array}{l}\text { Vascular } \\
\text { malformation type }\end{array}$} & \multicolumn{2}{|l|}{ Period $1(n=12)$} & \multicolumn{2}{|l|}{ Period $2(n=9)$} \\
\hline & $\begin{array}{l}\text { Response after } 6 \text { months of } \\
\text { sirolimus }\end{array}$ & $\begin{array}{l}\text { Vascular } \\
\text { malformation } \\
\text { size as assessed } \\
\text { using MRI }\end{array}$ & $\begin{array}{l}\text { Response after } 12 \text { months of } \\
\text { sirolimus }\end{array}$ & $\begin{array}{l}\text { Vascular } \\
\text { malformation } \\
\text { size as assessed } \\
\text { using MRI }\end{array}$ \\
\hline $\mathrm{VM}(n=2)$ & $\begin{array}{l}\text { Improvement of symptoms (pain, } \\
\text { QoL) (2) }\end{array}$ & $\begin{array}{l}\text { Decrease (1) } \\
\text { No MRI (1) }\end{array}$ & $\begin{array}{l}\text { Pain free }(1) \\
\text { Not restarted (1) }\end{array}$ & $\begin{array}{l}\text { Decrease }(1) \\
\text { Not restarted (1) }\end{array}$ \\
\hline $\mathrm{LM}(n=5)$ & $\begin{array}{l}\text { Improvement of symptoms (pain, } \\
\text { QoL, leakage, infections, } \\
\text { decrease of clinical size of LM, } \\
\text { etc.) (5) }\end{array}$ & $\begin{array}{l}\text { No change (2) } \\
\text { Decrease (2) } \\
\text { No MRI (1) }\end{array}$ & $\begin{array}{l}\text { Improvement of symptoms } \\
\text { (pain, QoL, leakage, decrease } \\
\text { of clinical size of LM, etc.) (2) } \\
\text { No change (1) } \\
\text { Not restarted (1) } \\
\text { Restarted with mTOR inhibitor } \\
\text { (1) }\end{array}$ & $\begin{array}{l}\text { No change (1) } \\
\text { Decrease (1) } \\
\text { Not restarted (1) } \\
\text { Restarted with } \\
\text { mTOR } \\
\text { inhibitor (1) } \\
\text { Unknown (1) }\end{array}$ \\
\hline $\begin{array}{l}\text { Lymphangiomatosis } \\
\qquad(n=1)\end{array}$ & No change (1) & Decrease (1) & No change in symptoms (1) & Increase $(1)$ \\
\hline $\operatorname{LVM}(n=2)$ & $\begin{array}{l}\text { Improvement of symptoms (pain, } \\
\text { clinical size of LVM) (2) }\end{array}$ & $\begin{array}{l}\text { No change (1) } \\
\text { No MRI (1) }\end{array}$ & $\begin{array}{l}\text { Pain reduction (2) } \\
\text { Clinical size reduction LVM (1) }\end{array}$ & $\begin{array}{l}\text { No change (1) } \\
\text { Unknown (1) }\end{array}$ \\
\hline $\operatorname{KTS}(n=2)$ & $\begin{array}{l}\text { Improvement of symptoms (pain, } \\
\text { QoL) (2) }\end{array}$ & $\begin{array}{l}\text { No change (1) } \\
\text { No MRI (1) }\end{array}$ & $\begin{array}{l}\text { Improvement of symptoms } \\
\text { (pain, clinical size reduction) } \\
\text { (2) }\end{array}$ & $\begin{array}{l}\text { No change (1) } \\
\text { Unknown (1) }\end{array}$ \\
\hline Total & $\begin{array}{l}\text { Improvement of symptoms (11; } \\
92 \%) \\
\text { No change }(1 ; 8 \%)\end{array}$ & $\begin{array}{l}\text { No change }(4 ; \\
33 \%) \\
\text { Decrease }(4 ; 33 \%) \\
\text { No MRI }(4 ; 33 \%)\end{array}$ & $\begin{array}{l}\text { Improvement of symptoms } \\
\text { (pain, QoL, leakage, decrease } \\
\text { of clinical size of LM, etc.) (7; } \\
78 \%) \\
\text { No change }(2 ; 122 \%) \\
\text { Not restarted }(2 ; 22 \%) \\
\text { Restarted with mTOR inhibitor } \\
(1 ; 11 \%)\end{array}$ & $\begin{array}{l}\text { No change (3; } \\
\text { 33\%) } \\
\text { Decrease (2; 22\%) } \\
\text { Increase (1; 11\%) } \\
\text { Not restarted (2; } \\
22 \%) \\
\text { Restarted with } \\
\text { mTOR } \\
\text { inhibitor (1; } \\
11 \%) \\
\text { Unknown (3; } \\
33 \%)\end{array}$ \\
\hline
\end{tabular}

$V M$ venous malformation, $L M$ lymphatic malformation, $L V M$ lymphatico-venous malformation, KTS Klippel-Trénaunay-Weber syndrome 


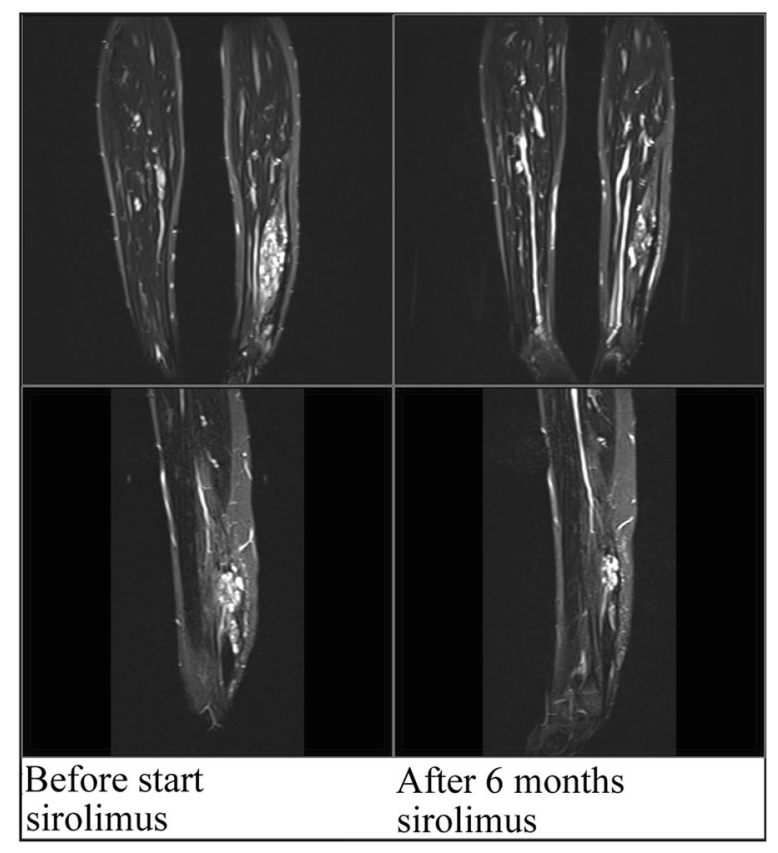

Fig. 1 Coronal and sagittal T2-weighted MRI images obtained from patient 5 , showing changes in the venous malformation located in her left lower extremity

During this phase generalized grade I-II skin lesions developed, which were treated with antibiotics and disappeared again. The QoL improved significantly and the girl was able again to do everything her peers were doing, too. After a few months, however, pain increased during menstrual periods. For that reason, sirolimus dosage was increased (target levels $6 \mathrm{ng} / \mathrm{ml}$ ). During the period that followed, the patient was pain free, though the menstrual cycles became irregular. For several months the girl did not have her menses and it was decided to stop sirolimus. Next, hypermenorrhea followed that proceeded for 5 weeks. In this period the pain of the calf returned, which disabled her again. Sirolimus was restarted and a new MRI was planned. This MRI showed a further reduction of the vascular malformation which made surgery possible. During surgery, more than $80 \%$ of the vascular malformation could be removed. Genetic analysis of the removed tissue revealed a PIK3CA genetic alteration. After surgery the girl was pain free for almost 5 months, but unfortunately the pain slowly returned. Eight months after surgery, pain symptoms were so severe that the patient was compelled to restart sirolimus. Interestingly, higher dosages were necessary to get her pain free than in the past. At this time point, she is 19 years old and still using sirolimus with no long-term adverse events. The menstrual cycles are regular. Sometimes the girl has an aphthous lesion but this is the only adverse event she suffers from.

\section{Case 2}

The girl presented here was right after birth diagnosed with a lymphatic malformation of the tongue and mouth, and suffered severe macroglossia (Fig. 2). A life-threatening situation in the first months after birth led to the need for a tracheostomy to guarantee an open airway for a longer time period. Before starting sirolimus, the patient had a substantially reduced QoL, experiencing repeated periods of hospitalization and no normal development of speech or possibilities for normal feeding. In the first weeks after the start of the sirolimus treatment, a rapid decrease in the size of the lowflow vascular malformation was observed. The sirolimus target levels ranged between 4.4 and $6.0 \mathrm{ng} / \mathrm{ml}$ during this period. After 6 months of treatment, an MRI was performed to quantify the response to sirolimus, which showed a clear reduction in the lymphatic malformation (Fig. 3). After 6 months it was decided to stop sirolimus. However, within 6 weeks after interruption of treatment, her tongue volume increased, noduli and nodus were present on the tongue, and the girl complained of pain. After restarting sirolimus, complaints disappeared again and the vascular malformation further reduced in size. At the age of 3 years, after using sirolimus for 21 months, a surgical intervention was possible. The tongue was reduced significantly and the tracheostomy was removed. Histological review revealed a PIK3CA genetic mutation.

During treatment with sirolimus, the girl experienced some adverse events like intermittent aphthous stomatitis, upper airway infections, tonsillitis, and elevation of triglycerides all grade I or II according the CTCAE criteria. After surgical intervention, she remained free of 


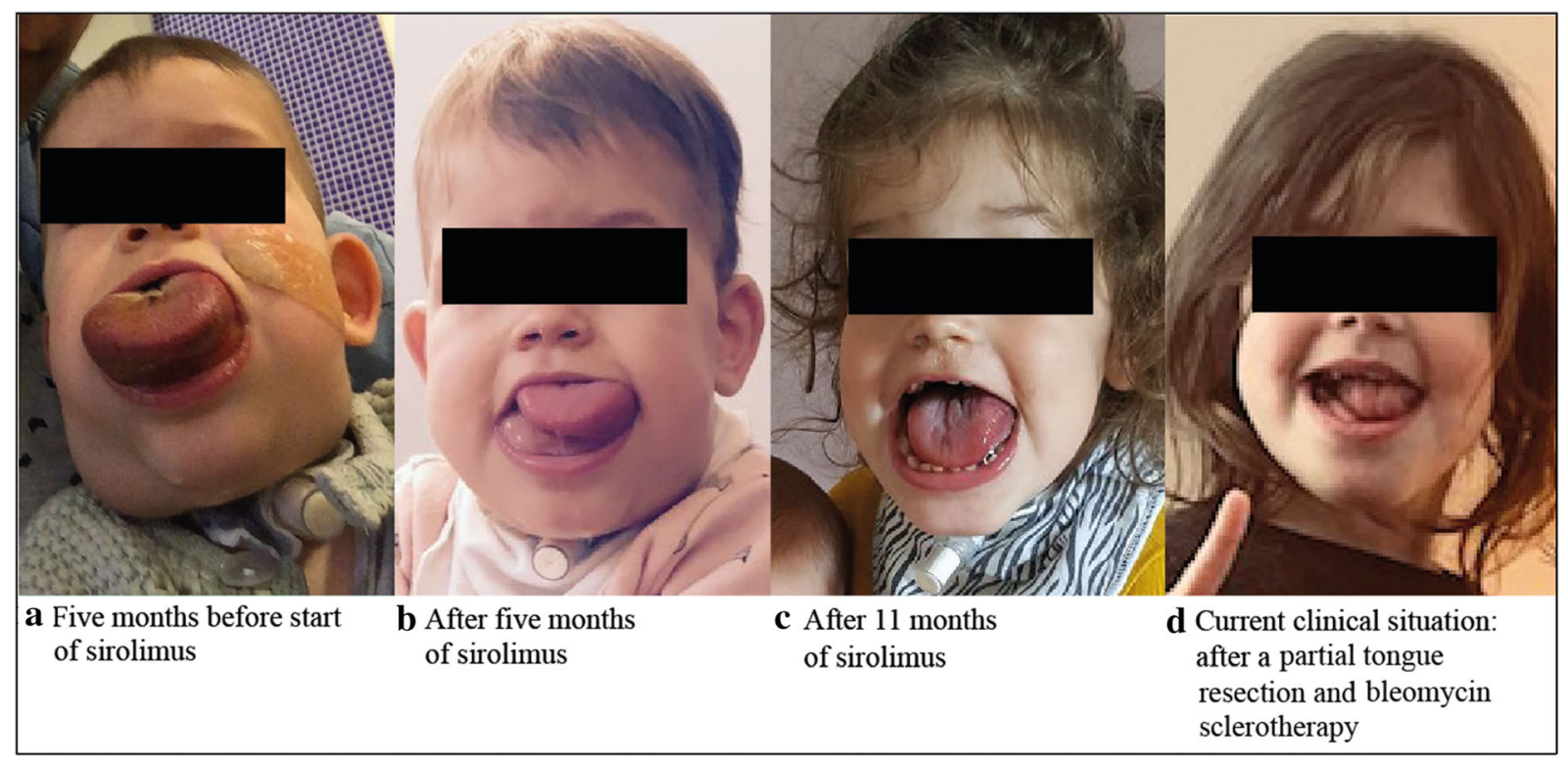

Fig. 2 Photographs obtained from patient 10, showing the changes in the submandibular- and neck-localized lymphatic malformation. a Five months before starting sirolimus, $\mathbf{b}$ after 5 months of sirolimus, $\mathbf{c}$ after 11 months of sirolimus, d current clinical situation: after partial tongue resection and bleomycin sclerotherapy

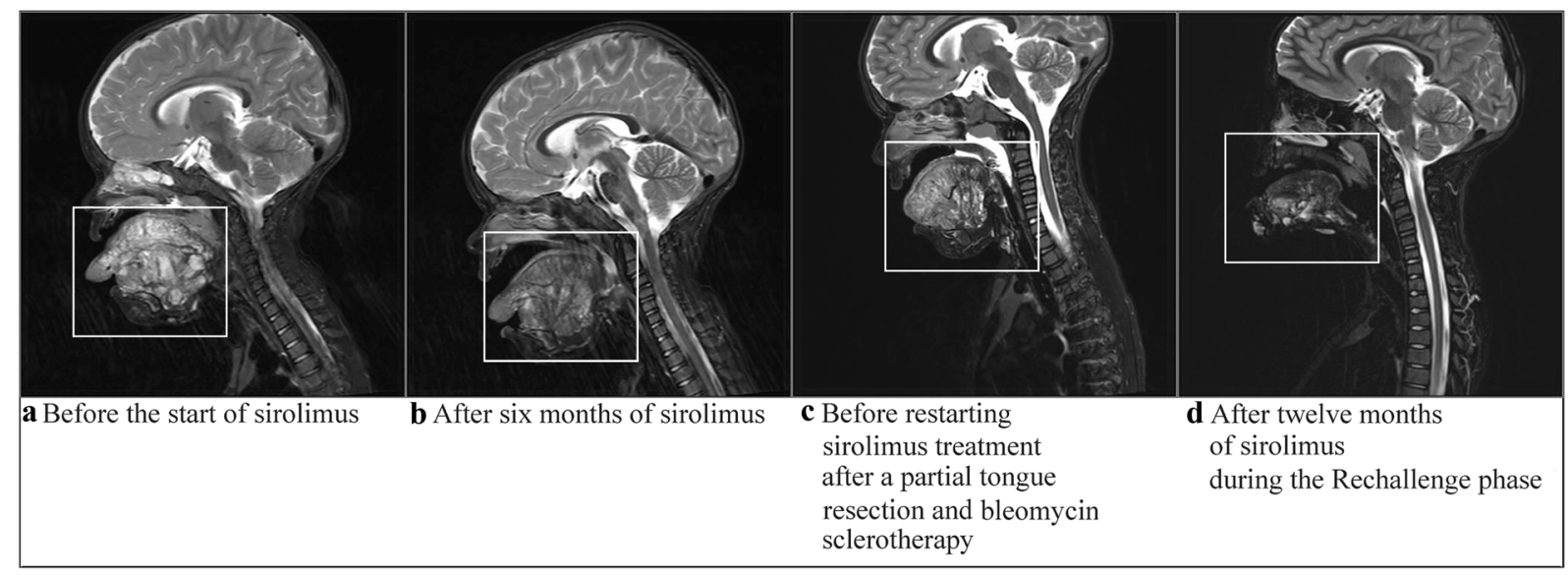

Fig. 3 T2-weighted MRI images obtained from patient 10 , showing changes in the submandibular- and neck-localized lymphatic malformation. The white boxes indicate the location of the lymphatic malformation. a Before starting sirolimus treatment, $\mathbf{b}$ after 6 months of

complaints for a period of 19 months. After 19 months there was new swelling of the tongue, pain returned, and she developed blisters on the tongue. Sirolimus was restarted. Now she is 6 years old and has developed as a normal sirolimus treatment, $\mathbf{c}$ before restarting sirolimus treatment after a partial tongue resection and bleomycin sclerotherapy, $\mathbf{d}$ after 12 months of sirolimus during the restart of sirolimus

child. She did have some viral infectious diseases like other children have at this age. There were no opportunistic infections or other problems so far. 


\section{Adverse and Unanticipated Events}

All patients experienced adverse events when taking sirolimus either during the first phase of treatment or during rechallenge. The most frequent adverse events that were likely related to sirolimus treatment were aphthous stomatitis grade I ( $50 \%$ of patients) and menstrual disorder grades I-II. Menstrual disturbances were observed in all three female patients older than 11 years (patients 1,3 , and 5). Even though the menstrual cycles were regular in all three patients without sirolimus, the cycles became very irregular with periods of 3-4 months without menstruation. This was followed by a period of intense blood loss after sirolimus was stopped. These problems were mainly observed after a longer exposure time of sirolimus. Two patients (16.7\%) experienced grades I-II bone marrow toxicity. Reasons for a temporary stop (several days) of sirolimus were vaccination $(n=1)$, interventional radiology (bleomycin sclerotherapy $n=2)$, decannulation $(n=1)$, and adverse events: infections $(n=13)$ of which sepsis $(n=1)$, menstrual disorder $(n=2)$, aphthous stomatitis $(n=1)$, general malaise $(n=1)$, and elevated liver enzymes $(n=1)$. Therapylimiting adverse events were seen in two patients: one patient had a grade II increase of liver enzymes after 5 months of sirolimus treatment, leading to interruption of treatment and one patient had a grade II menorrhagia after 36 months of sirolimus treatment. All adverse events were resolved by interrupting treatment.

\section{Long-Term Follow-up and Outcomes}

Median follow-up time of the nine patients that continued treatment with sirolimus was 4.8 years (range 3.3-6 years) (Table 2). In two of the nine patients reinduction of sirolimus did not give the desired result and sirolimus was discontinued after 1 year. Patients were followed over the years to evaluate whether there were long-term adverse events caused by sirolimus. Up to now, no adverse events have been reported. The other seven patients continued sirolimus, with interruptions of sirolimus in case of infections or irregular menstruations. In two patients, sirolimus was interrupted for a longer time period because of surgical intervention. In none of the patients that are still using sirolimus have long-term adverse events been observed. However, they all sometimes have aphthous lesions in the mouth which do not require treatment. While the female patients had irregular menstruations in the first year, it seems that longer use of sirolimus leads to stabilization of the cycle. To date, none of these patients developed other adverse events such as diabetes, interstitial pneumonitis, lifethreatening infections, or severe bone marrow toxicity. All seven patients have a significant improvement of QoL as reported by themselves.

\section{DISCUSSION}

We present the results of a case series for determination of the efficacy and safety of low dose sirolimus on low-flow vascular malformations. A positive response of $92 \%(n=11 / 12)$ in the first treatment period was seen, and after sirolimus was restarted a response of $78 \%$ $(n=7 / 9)$ was achieved. Two patients did not experience a reduction in symptoms after restarting the treatment. In one patient, a positive response was seen in the first treatment period but not during the restart period. This could be attributed to resistance in the restart period or to a placebo effect during the first phase; however, DNA diagnostics were not performed in this patient, so the genetic basis and resulting sensitivity of the vascular malformation could not be explored. In the other patient lacking a positive response in the second phase, DNA diagnostics revealed no mutations.

Genetic testing of the vascular malformation was not performed routinely; however, in three out of four patients, DNA diagnostics on tissue revealed a PIK3CA mutation. In the other patient, no genetic aberrations could be found using our vascular anomalies panel [5]. One hypothesis relating to these non-responders may be a mutation in a different pathway, e.g., the RAS/BRAF/MAPK/ERK pathway which also stimulates angiogenesis [29]. However, clinical 
Table 2 Long-term follow-up efficacy and safety

\begin{tabular}{|c|c|c|c|c|c|c|}
\hline $\begin{array}{l}\text { Patient } \\
\text { no. }\end{array}$ & $\begin{array}{l}\text { Follow- } \\
\text { up } \\
\text { period } \\
\text { (months) }\end{array}$ & $\begin{array}{l}\text { Duration of } \\
\text { return of pain/ } \\
\text { symptoms after } \\
\text { stopping sirolimus }\end{array}$ & $\begin{array}{l}\text { Total } \\
\text { duration of } \\
\text { sirolimus } \\
\text { intake }\end{array}$ & $\begin{array}{l}\text { Recurrent related } \\
\text { adverse events } \\
\text { (grade; relation to } \\
\text { sirolimus) }\end{array}$ & $\begin{array}{l}\text { Overall } \\
\text { therapeutic } \\
\text { response }\end{array}$ & $\begin{array}{l}\text { Duration of stop } \\
\text { since last sirolimus } \\
\text { use until last } \\
\text { follow-up; } \\
\text { complaints after } \\
\text { last stoppage }\end{array}$ \\
\hline 1 & 58 & $\begin{array}{l}\text { After the second } \\
\text { period of } \\
\text { sirolimus, patient } \\
\text { is not restarted }\end{array}$ & 36 months & $\begin{array}{l}\text { Recurrent } \\
\text { aphthous } \\
\text { stomatitis and } \\
\text { menorrhagia } \\
\text { during use of } \\
\text { sirolimus. No } \\
\text { long-term } \\
\text { adverse events } \\
\text { observed }\end{array}$ & $\begin{array}{l}\text { Pain free during } \\
\text { sirolimus use }\end{array}$ & $\begin{array}{l}10 \text { months; pain } \\
\text { symptoms are } \\
\text { tolerable, no use } \\
\text { of pain } \\
\text { medication }\end{array}$ \\
\hline 2 & 72 & $\begin{array}{l}\text { During stoppage of } \\
\text { several weeks } \\
\text { patient } \\
\text { experienced } \\
\text { reoccurrence of } \\
\text { his pain and } \\
\text { lymph leakage }\end{array}$ & $\begin{array}{l}33 \text { months } \\
\text { and } \\
\text { ongoing }\end{array}$ & $\begin{array}{l}\text { No long-term } \\
\text { adverse events } \\
\text { observed }\end{array}$ & $\begin{array}{l}\text { Pain free during } \\
\text { sirolimus use, } \\
\text { improvement of } \\
\text { QoL }\end{array}$ & $\begin{array}{l}\text { Recently restarted } \\
\text { because of } \\
\text { recurrence of } \\
\text { symptoms }\end{array}$ \\
\hline 3 & 62 & $\begin{array}{l}\text { After the second } \\
\text { period of } \\
\text { sirolimus, patient } \\
\text { is not restarted }\end{array}$ & 23 months & $\begin{array}{l}\text { No long-term } \\
\text { adverse events } \\
\text { observed }\end{array}$ & $\begin{array}{l}\text { Reduction of } \\
\text { complaints but } \\
\text { not completely } \\
\text { free of pain }\end{array}$ & $\begin{array}{l}25 \text { months; after } \\
\text { treatment of } \\
\text { sirolimus } \\
\text { bleomycin } \\
\text { sclerotherapy; } \\
\text { however, pain } \\
\text { complaints } \\
\text { continued }\end{array}$ \\
\hline 4 & 46 & $\begin{array}{l}\text { After the second } \\
\text { period of } \\
\text { sirolimus, patient } \\
\text { is not restarted }\end{array}$ & 10 months & $\begin{array}{l}\text { No long-term } \\
\text { adverse events } \\
\text { observed }\end{array}$ & No remission & $\begin{array}{l}32 \text { months; status } \\
\text { quo ante }\end{array}$ \\
\hline
\end{tabular}


Table 2 continued

\begin{tabular}{|c|c|c|c|c|c|c|}
\hline $\begin{array}{l}\text { Patient } \\
\text { no. }\end{array}$ & $\begin{array}{l}\text { Follow- } \\
\text { up } \\
\text { period } \\
\text { (months) }\end{array}$ & $\begin{array}{l}\text { Duration of } \\
\text { return of pain/ } \\
\text { symptoms after } \\
\text { stopping sirolimus }\end{array}$ & $\begin{array}{l}\text { Total } \\
\text { duration of } \\
\text { sirolimus } \\
\text { intake }\end{array}$ & $\begin{array}{l}\text { Recurrent related } \\
\text { adverse events } \\
\text { (grade; relation to } \\
\text { sirolimus) }\end{array}$ & $\begin{array}{l}\text { Overall } \\
\text { therapeutic } \\
\text { response }\end{array}$ & $\begin{array}{l}\text { Duration of stop } \\
\text { since last sirolimus } \\
\text { use until last } \\
\text { follow-up; } \\
\text { complaints after } \\
\text { last stoppage }\end{array}$ \\
\hline 5 & 63 & $\begin{array}{l}\text { After each } \\
\text { (temporary) } \\
\text { stoppage patient } \\
\text { experienced } \\
\text { reoccurrence of } \\
\text { pain symptoms }\end{array}$ & $\begin{array}{l}3.5 \text { years } \\
\text { and } \\
\text { ongoing }\end{array}$ & $\begin{array}{l}\text { Repeated } \\
\text { menstrual } \\
\text { disturbances } \\
\text { during sirolimus } \\
\text { use and } \\
\text { intermittent } \\
\text { atopic dermatitis. } \\
\text { No long-term } \\
\text { adverse events } \\
\text { observed }\end{array}$ & $\begin{array}{l}\text { Pain free } \\
\text { several weeks } \\
\text { after each start } \\
\text { during sirolimus } \\
\text { use, partial } \\
\text { resection possible } \\
\text { after sirolimus } \\
\text { use }\end{array}$ & Currently ongoing \\
\hline 6 & 13 & Not restarted & $\begin{array}{l}\text { Not } \\
\quad \text { restarted }\end{array}$ & & & \\
\hline 7 & 54 & $\begin{array}{l}\text { Restarted with } \\
\text { mTOR inhibitor }\end{array}$ & $\begin{array}{l}41 \text { months } \\
\text { and } \\
\text { ongoing }\end{array}$ & $\begin{array}{l}\text { No long-term } \\
\text { adverse events } \\
\text { observed }\end{array}$ & $\begin{array}{l}\text { Partial remission: } \\
\text { less pain, fewer } \\
\text { infections }\end{array}$ & Currently ongoing \\
\hline 8 & 40 & $\begin{array}{l}\text { After the second } \\
\text { period of } \\
\text { sirolimus, patient } \\
\text { is not restarted }\end{array}$ & 8 months & $\begin{array}{l}\text { No long-term } \\
\text { adverse events } \\
\text { observed }\end{array}$ & $\begin{array}{l}\text { Pain free during } \\
\text { sirolimus use }\end{array}$ & $\begin{array}{l}\text { Lost to follow-up } \\
\text { probable restarted } \\
\text { with sirolimus- } \\
\text { patient was } \\
\text { referred to local } \\
\text { hospital for } \\
\text { continuing } \\
\text { sirolimus therapy }\end{array}$ \\
\hline 9 & 58 & $\begin{array}{l}\text { After each } \\
\text { (temporary) } \\
\text { stoppage patient } \\
\text { experience } \\
\text { reoccurrence of } \\
\text { pain symptoms, } \\
\text { and reduction of } \\
\text { pain after restart } \\
\text { sirolimus }\end{array}$ & Ongoing & $\begin{array}{l}\text { Intermittent } \\
\text { neutropenia and } \\
\text { intercurrent } \\
\text { infections } \\
\text { No long-term } \\
\text { adverse events } \\
\text { observed }\end{array}$ & Pain reduction & Currently ongoing \\
\hline
\end{tabular}


Table 2 continued

\begin{tabular}{|c|c|c|c|c|c|c|}
\hline $\begin{array}{l}\text { Patient } \\
\text { no. }\end{array}$ & $\begin{array}{l}\text { Follow- } \\
\text { up } \\
\text { period } \\
\text { (months) }\end{array}$ & $\begin{array}{l}\text { Duration of } \\
\text { return of pain/ } \\
\text { symptoms after } \\
\text { stopping sirolimus }\end{array}$ & $\begin{array}{l}\text { Total } \\
\text { duration of } \\
\text { sirolimus } \\
\text { intake }\end{array}$ & $\begin{array}{l}\text { Recurrent related } \\
\text { adverse events } \\
\text { (grade; relation to } \\
\text { sirolimus) }\end{array}$ & $\begin{array}{l}\text { Overall } \\
\text { therapeutic } \\
\text { response }\end{array}$ & $\begin{array}{l}\text { Duration of stop } \\
\text { since last sirolimus } \\
\text { use until last } \\
\text { follow-up; } \\
\text { complaints after } \\
\text { last stoppage }\end{array}$ \\
\hline 10 & 57 & $\begin{array}{l}\text { During each } \\
\text { stoppage of } \\
\text { sirolimus increase } \\
\text { of tongue volume }\end{array}$ & $\begin{array}{l}41 \text { months } \\
\text { and } \\
\text { ongoing }\end{array}$ & $\begin{array}{l}\text { Intermittent } \\
\text { aphthous } \\
\text { mucositis and } \\
\text { several viral } \\
\text { infections. No } \\
\text { long-term } \\
\text { adverse events } \\
\text { observed }\end{array}$ & $\begin{array}{l}\text { Decrease of volume } \\
\text { of low-flow } \\
\text { vascular } \\
\text { malformation in } \\
\text { the neck, tongue, } \\
\text { and } \\
\text { submandibular; } \\
\text { partial } \\
\text { submandibular } \\
\text { resection was } \\
\text { possible. Further } \\
\text { size reduction } \\
\text { following } \\
\text { submandibular } \\
\text { bleomycin } \\
\text { sclerosis, } \\
\text { decannulation, } \\
\text { and tongue } \\
\text { bleomycin } \\
\text { sclerosis because } \\
\text { of increased } \\
\text { tongue volume }\end{array}$ & Currently ongoing \\
\hline 11 & 55 & $\begin{array}{l}\text { After the second } \\
\text { period of } \\
\text { sirolimus, patient } \\
\text { is not restarted }\end{array}$ & $\begin{array}{l}10 \text { months, } \\
\text { stopped } \\
\text { after } \\
4 \text { months } \\
\text { of } \\
\text { sirolimus } \\
\text { use due to } \\
\text { inefficacy }\end{array}$ & $\begin{array}{l}\text { No long-term } \\
\text { adverse events } \\
\text { observed }\end{array}$ & $\begin{array}{l}\text { Pain only reduced } \\
\text { during challenge } \\
\text { phase, not } \\
\text { rechallenge phase }\end{array}$ & $\begin{array}{l}36 \text { months, } \\
\text { anticoagulation } \\
\text { therapy was } \\
\text { started, } \\
\text { nevertheless pain } \\
\text { symptoms } \\
\text { continues }\end{array}$ \\
\hline 12 & 8 & Not restarted & $\begin{array}{l}\text { Not } \\
\quad \text { restarted }\end{array}$ & & & \\
\hline
\end{tabular}

Outcomes of the case series study for 12 patients treated with sirolimus at Radboud University Medical Center, Nijmegen, the Netherlands 
Table 3 Adverse events observed in our case series compared to other studies

\begin{tabular}{|c|c|c|c|c|c|}
\hline $\begin{array}{l}\text { Adverse events } \\
\text { attributable to sirolimus }\end{array}$ & $\begin{array}{l}\text { Grade of } \\
\text { toxicity }\end{array}$ & $\begin{array}{l}\text { Pilot } \\
\text { study, } \\
n=12\end{array}$ & $\begin{array}{l}\text { Adams et al. }{ }^{\mathrm{a}}, \\
n=\mathbf{5 7}\end{array}$ & $\begin{array}{l}\text { Hammer } \\
\text { et al. } \\
n=19\end{array}$ & Nguyen et al..$^{c}$ review \\
\hline \multirow[t]{2}{*}{ Blood/bone marrow toxicity } & $\begin{array}{l}\text { Grade I and } \\
\text { II }\end{array}$ & $2(17 \%)$ & $\begin{array}{l}\text { Grade II or higher: } \\
30(49 \%)\end{array}$ & $1(5 \%)$ & $11-76 \%$ \\
\hline & Grade $\geq$ III & $0(0 \%)$ & $16(27 \%)$ & $1(5 \%)$ & \\
\hline \multirow[t]{2}{*}{$\begin{array}{l}\text { Gastrointestinal toxicity (e.g., } \\
\text { mucositis) }\end{array}$} & $\begin{array}{l}\text { Grade I and } \\
\text { II }\end{array}$ & $9(75 \%)$ & $\begin{array}{l}\text { Grade II or higher: } \\
33(55 \%)\end{array}$ & $19(100 \%)$ & $3-19 \%$ \\
\hline & Grade $\geq$ III & $0(0 \%)$ & $2(3 \%)$ & $2(11 \%)$ & \\
\hline \multirow[t]{2}{*}{ Metabolic/laboratory toxicity } & $\begin{array}{l}\text { Grade I and } \\
\text { II }\end{array}$ & $4(33 \%)$ & $\begin{array}{l}\text { Grade II or higher: } \\
12(20 \%)\end{array}$ & $0(0 \%)$ & $20-64 \%$ \\
\hline & Grade $\geq$ III & $0(0 \%)$ & $2(3 \%)$ & $0(0 \%)$ & \\
\hline \multirow[t]{2}{*}{ Infection } & $\begin{array}{l}\text { Grade I and } \\
\text { II }\end{array}$ & $6(50 \%)$ & $\begin{array}{l}\text { Grade II or higher: } \\
\quad 9(15 \%)\end{array}$ & $6(32 \%)$ & Unknown \\
\hline & Grade $\geq$ III & $0(0 \%)$ & $1(2 \%)$ & $0(0 \%)$ & \\
\hline \multirow[t]{2}{*}{ Endocrine toxicity } & $\begin{array}{l}\text { Grade I and } \\
\text { II }\end{array}$ & $3(25 \%)$ & Unknown & Unknown & $\begin{array}{l}\text { 20-27\% (diabetes } \\
\text { mellitus) }\end{array}$ \\
\hline & Grade $\geq$ III & $0(0 \%)$ & Unknown & Unknown & \\
\hline \multirow[t]{2}{*}{ Dermatology toxicity } & $\begin{array}{l}\text { Grade I and } \\
\text { II }\end{array}$ & $3(25 \%)$ & $5(8 \%)$ & $7(36.9 \%)$ & Unknown \\
\hline & Grade $\geq$ III & $0(0 \%)$ & Unknown & $1(5.3 \%)$ & \\
\hline \multirow[t]{2}{*}{ Neurologic toxicity } & $\begin{array}{l}\text { Grade I and } \\
\text { II }\end{array}$ & $4(33 \%)$ & Unknown & $12(63 \%)$ & Unknown \\
\hline & Grade $\geq$ III & $0(0 \%)$ & Unknown & $0(0 \%)$ & \\
\hline \multirow[t]{2}{*}{$\begin{array}{l}\text { Pulmonary/upper respiratory } \\
\text { toxicity }\end{array}$} & $\begin{array}{l}\text { Grade I and } \\
\text { II }\end{array}$ & $7(58 \%)$ & $\begin{array}{l}\text { Grade II or higher: } \\
\quad 1(2 \%)\end{array}$ & $1(5 \%)$ & Unknown \\
\hline & Grade $\geq$ III & $0(0 \%)$ & $1(2 \%)$ & $0(0 \%)$ & \\
\hline \multirow[t]{2}{*}{ Interstitial lung disease } & $\begin{array}{l}\text { Grade I and } \\
\text { II }\end{array}$ & $0(0 \%)$ & Unknown & Unknown & $4-17 \%$ \\
\hline & Grade $\geq$ III & $0(0 \%)$ & Unknown & Unknown & \\
\hline \multirow[t]{2}{*}{ Musculoskeletal/soft tissue } & $\begin{array}{l}\text { Grade I and } \\
\text { II }\end{array}$ & $1(8 \%)$ & $0(0 \%)$ & $0(0 \%)$ & Unknown \\
\hline & Grade $\geq$ III & $0(0 \%)$ & $0(0 \%)$ & $0(0 \%)$ & \\
\hline
\end{tabular}


Table 3 continued

\begin{tabular}{|c|c|c|c|c|c|}
\hline $\begin{array}{l}\text { Adverse events } \\
\text { attributable to sirolimus }\end{array}$ & $\begin{array}{l}\text { Grade of } \\
\text { toxicity }\end{array}$ & $\begin{array}{l}\text { Pilot } \\
\text { study, } \\
n=12\end{array}$ & $\begin{array}{l}\text { Adams et al. }{ }^{\mathrm{a}}, \\
n=\mathbf{5 7}\end{array}$ & $\begin{array}{l}\text { Hammer } \\
\text { et al. }^{\mathbf{b}} \\
n=19\end{array}$ & Nguyen et al..$^{c}$ review \\
\hline \multirow{3}{*}{$\begin{array}{l}\text { General symptoms (e.g., } \\
\text { hypertension/wound } \\
\text { healing) }\end{array}$} & $\begin{array}{l}\text { Grade I and } \\
\text { II }\end{array}$ & $1(8 \%)$ & $\begin{array}{l}\text { Cardiac general: } 0 \\
(0 \%)\end{array}$ & $20(105 \%)$ & \multirow{3}{*}{$\begin{array}{l}\text { Angioedema } \\
(2.2-15 \%) \text {, urologic } \\
(12 \%)\end{array}$} \\
\hline & Grade $\geq$ III & $0(0 \%)$ & $\begin{array}{l}\text { Cardiac general: } 0 \\
(0 \%)\end{array}$ & $0(0 \%)$ & \\
\hline & & & $\begin{array}{l}\text { Constitutional } \\
\text { symptoms: } 0 \\
(0 \%)\end{array}$ & & \\
\hline \multirow[t]{2}{*}{ Lymphedema } & $\begin{array}{l}\text { Grade I and } \\
\text { II }\end{array}$ & $0(0 \%)$ & $\begin{array}{l}\text { Grade II or higher: } \\
4(7 \%)\end{array}$ & Unknown & \multirow[t]{2}{*}{$6.4-12 \%$} \\
\hline & Grade $\geq$ III & $0(0 \%)$ & $1(2 \%)$ & Unknown & \\
\hline
\end{tabular}

Adverse events observed in our pilot study and those reported in the studies performed by Adams et al. and Hammer et al. and Nguyen et al.'s review

${ }^{a}$ Adams et al.: patients with various complex vascular anomalies (including vascular tumors), target levels $10-15 \mathrm{ng} / \mathrm{ml}$ [14]

b Hammer et al.: patients with a vascular malformation using target levels $10-15 \mathrm{ng} / \mathrm{ml}$ [16]. The table shows a $105 \%$ percentage due to categorizing and summarizing patients with general symptoms

${ }^{c}$ Nguyen et al.'s review of sirolimus in solid organ transplantation identified a wide array of adverse effects [12]

appearance did not correspond to a mutation in this pathway. Another possible theory is that the duration of 6 or 12 months is not long enough for those patients who are potential late responders.

The results of this case series are comparable to those reported in the literature despite the lower target level of sirolimus used (response rates, respectively, $85 \%$ Adams et al., $20-80 \%$ Nadal et al. versus $78-92 \%$ in the present case series $[14,30])$.

At the same time less serious adverse events were seen in this case series compared to other high dose clinical studies. For example bone marrow toxicity was not observed in the present case series, whereas in the phase II trial by Adams et al. $27 \%$ of the patients developed a bone marrow toxicity of grade III or higher. In addition, Schena et al. reported a bone marrow toxicity in $13.4-36.3 \%$ of renal allograft recipients using target trough levels of $8-20 \mathrm{ng} / \mathrm{ml}$ [25] and Nguyen et al. described in their review that bone marrow toxicity can be observed in
$11-76 \%$ of the patients [12] (see Table 3). As in most drugs observed, one can imagine that higher levels of a drug increase the risk of developing adverse events of which the most serious and sometimes even fatal complication is sirolimus-associated interstitial pneumonitis [17-19, 27].

Bee et al. showed that low sirolimus serum levels (less than 3 and $6.9 \mathrm{ng} / \mathrm{ml}$ ) are related to less side effects without compromising efficacy of treatment in patients with diffuse lymphangioleiomyomatosis [31]. Additionally, Kahan et al. showed a significant relation between the occurrence of adverse events (hypertriglyceridemia, hypercholesterolemia, leukopenia, and thrombocytopenia) and the steady state concentration value of sirolimus [21]. A $C_{\mathrm{ss}}$ below $10 \mathrm{ng} / \mathrm{L}$ showed no toxic values.

Taken together, the observation and that of our case series support our hypothesis that reduction of the sirolimus target trough concentration range from high target level $10-15 \mathrm{ng} / \mathrm{ml}$ to low target level $4-10 \mathrm{ng} / \mathrm{ml}$ does 
not decrease efficacy but improves tolerance. Parker et al. used even lower target level of sirolimus $(2-6 \mathrm{ng} / \mathrm{ml})$ in 39 patients with PIK3CArelated overgrowth spectrum (PROS) [32]. The results showed that with these low levels of sirolimus, overgrowth was reduced; a significant reduction of $7.2 \%$ was seen in the volume of affected tissues.

None of the studies published regarding the use of sirolimus in vascular malformations describes problems in the menstrual cycles which were found in all three female adolescent cases of our case series. All three suffered from irregular menstrual cycles with a long-term period without menstruations followed by a long period (5 weeks- 2 months) of bleeding. In clinical studies using sirolimus for a different patient category, however, it is described that low dose orally administered sirolimus increases the risk of menstrual cycle disturbances as found in three of the female adolescents of our case series. Furthermore, in patients with autosomal dominant polycystic kidney disease it is described that ovarian cysts might develop during treatment with sirolimus [33]. Of course, this is a different disease entity; however, at the same time there is still a lot to learn about adverse events that may occur in patients with sirolimus and adverse events observed in different diseases have to be monitored closely. There is a tendency to start treatment of patients with congenital vascular malformations at pediatric age, whereas at the same time we still do not know what long-terms sequelae might develop. Although the present case series is still small, they were followed over a longer time period and with the low target levels of sirolimus no serious long-term adverse events were observed, not even in the three female patients that had menstrual cycle disturbances. They all recovered and currently have a normal menstrual cycle, although we can only speculate whether there are consequences regarding fertility.

Our knowledge regarding long-term toxicities of sirolimus is still expanding. For example, it has been observed that in patients with longterm sirolimus impaired insulin receptor substrate signaling and Akt activation can be found, indicating a deterioration of glucose metabolism leading to an increase of development of diabetes [34]. It is essential for the future application of sirolimus that one gain more insight into these aspects. Currently several studies are ongoing to study efficacy and safety of sirolimus in more detail. As congenital vascular malformations belong to the group of rare diseases it is essential to combine the results of these different studies. The long-term followup of patients that are now in the pediatric age and will use sirolimus for a long-term period is vital; sirolimus will not cure them, but only control the vascular malformation and in this way reduce their complaints. Patients have the right to be well informed on potential adverse events, and such events can occur even if sirolimus is applied in low dose. The results of case series have led to the development of a nationwide clinical trial (EUDRACT number 2016-002157-38; www.clinicaltrials.gov, identifier NCT03987152) to gain more insight into efficacy and adverse events if low dose sirolimus is used. All patients will be followed over a long time period to obtain more data regarding longterm sequelae and gaining more insight into the consequence of menstrual disturbances in young female patients.

\section{CONCLUSION}

This case series demonstrates that low dose sirolimus is as effective as high dose sirolimus in patients with congenital vascular malformations. At the same time less serious adverse events are observed than those previously described. At the same time a new adverse event, namely menstrual cycle disturbance, was observed in young adolescents, indicating the need for caution when sirolimus is given. This is extremely relevant to patients with low-flow vascular malformation, who are likely to require lifelong treatment for their condition.

\section{ACKNOWLEDGEMENTS}

We would like to thank Ingrid van Rijnsoever for her excellent contribution of collecting informed consent and data. We want to thank 
our patients for their involvement in the case series.

Funding. Pfizer (New York city, New York, United States) supported this case series by offering Sirolimus (Rapamune ${ }^{\circledR}$ ). No funding or sponsorship was received for publication of this article. The Rapid Service Fee was funded by the authors.

Authorship. All named authors meet the International Committee of Medical Journal Editors (ICMJE) criteria for authorship for this article, take responsibility for the integrity of the work as a whole, and have given their approval for this version to be published.

Author contributions. VH writing the manuscript and analyzed and interpreted the patient data, GR treated patients in this case series, substantively revised the manuscript, CvdV substantively revised the manuscript, PdL substantively revised the manuscript, WK substantively revised the manuscript, LSK substantively revised the manuscript, MtL treated all pediatric patients in this case series, analyzed and interpreted the patient data, significantly contributed in writing the manuscript. All authors read and approved the final manuscript.

Disclosures. Veroniek E.M. Harbers, Gerard A.P.J.M. Rongen, Carine J.M. van der Vleuten, Bas H. Verhoeven, Peter C.J. de Laat, Chantal M.A.M. van der Horst, Willemijn M. Klein, Leo J. Schultze Kool, D. Maroeska W.M. te Loo declare that they have no competing interests.

Compliance with ethics guidelines. The case series was approved as an nWMO study, i.e., non falling under the Medical Research Involving Human Subjects Act, by the research ethics committee (CMO Regio Arnhem-Nijmegen-institutional review board) in the Netherlands. The case series was performed in accordance with the Declaration of Helsinki and Good Clinical Practice guidelines. Informed consent was obtained in all patients before start. The illustrated patients and thier parents gave their consent for publication and image use.
Prior presentation. A poster presentation of this research was held at the ISSVA congress on the 13-14 May 2020.

Data availability. The datasets supporting the conclusions of this article are included within the article and its supplementary material.

Open Access. This article is licensed under a Creative Commons Attribution-NonCommercial 4.0 International License, which permits any non-commercial use, sharing, adaptation, distribution and reproduction in any medium or format, as long as you give appropriate credit to the original author(s) and the source, provide a link to the Creative Commons licence, and indicate if changes were made. The images or other third party material in this article are included in the article's Creative Commons licence, unless indicated otherwise in a credit line to the material. If material is not included in the article's Creative Commons licence and your intended use is not permitted by statutory regulation or exceeds the permitted use, you will need to obtain permission directly from the copyright holder. To view a copy of this licence, visit http://creativecommons.org/licenses/by$\mathrm{nc} / 4.0 /$.

\section{REFERENCES}

1. Wassef M, Blei F, Adams D, et al. Vascular anomalies classification: recommendations from the international society for the study of vascular anomalies. Pediatrics. 2015;136(1):e203-14.

2. Mulligan PR, Prajapati HJ, Martin LG, Patel TH. Vascular anomalies: classification, imaging characteristics and implications for interventional radiology treatment approaches. $\mathrm{Br} \mathrm{J}$ Radiol. 2014;87(1035):20130392.

3. Cox JA, Bartlett E, Lee EI. Vascular malformations: a review. Semin Plast Surg. 2014;28(2):58-63.

4. Akita S, Houbara S, Hirano A. Management of vascular malformations. Plast Reconstr Surg Glob Open. 2014;2(3):e128.

5. Ten Broek RW, Eijkelenboom A, van der Vleuten CJM, et al. Comprehensive molecular and 
clinicopathological analysis of vascular malformations: a study of 319 cases. Genes Chromosomes Cancer. 2019;58(8):541-50.

6. Keppler-Noreuil KM, Rios JJ, Parker VE, et al. PIK3CA-related overgrowth spectrum (PROS): diagnostic and testing eligibility criteria, differential diagnosis, and evaluation. Am J Med Genet A. 2015;167A(2):287-95.

7. Freed D, Stevens EL, Pevsner J. Somatic mosaicism in the human genome. Genes (Basel). 2014;5(4): 1064-94.

8. Boscolo E, Limaye N, Huang L, et al. Rapamycin improves TIE2-mutated venous malformation in murine model and human subjects. J Clin Invest. 2015;125(9):3491-504.

9. Nathan N, Keppler-Noreuil KM, Biesecker LG, Moss J, Darling TN. Mosaic disorders of the PI3K/PTEN/ AKT/TSC/mTORC1 signaling pathway. Dermatol Clin. 2017;35(1):51-60.

10. Guertin DA, Sabatini DM. Defining the role of mTOR in cancer. Cancer Cell. 2007;12(1):9-22.

11. Laplante $M$, Sabatini DM. mTOR signaling at a glance. J Cell Sci. 2009;122(Pt 20):3589-94.

12. Nguyen LS, Vautier M, Allenbach Y, et al. Sirolimus and mTOR inhibitors: a review of side effects and specific management in solid organ transplantation. Drug Saf. 2019;42(7):813-25.

13. Hammill AM, Wentzel M, Gupta A, et al. Sirolimus for the treatment of complicated vascular anomalies in children. Pediatr Blood Cancer. 2011;57(6): 1018-24.

14. Adams DM, Trenor CC 3rd, Hammill AM, et al. Efficacy and safety of sirolimus in the treatment of complicated vascular anomalies. Pediatrics. 2016;137(2):e20153257.

15. Lackner H, Karastaneva A, Schwinger W, et al. Sirolimus for the treatment of children with various complicated vascular anomalies. Eur J Pediatr. 2015;174(12):1579-84.

16. Hammer J, Seront E, Duez S, et al. Sirolimus is efficacious in treatment for extensive and/or complex slow-flow vascular malformations: a monocentric prospective phase II study. Orphanet J Rare Dis. 2018;13(1):191.

17. Morath C, Schwenger V, Ksoll-Rudek D, et al. Four cases of sirolimus-associated interstitial pneumonitis: identification of risk factors. Transplant Proc. 2007;39(1):99-102.
18. Singer SJ, Tiernan R, Sullivan EJ. Interstitial pneumonitis associated with sirolimus therapy in renaltransplant recipients. N Engl J Med. 2000;343(24): 1815-6.

19. Wang WL, Yu LX. Acute respiratory distress attributed to sirolimus in solid organ transplant recipients. Am J Emerg Med. 2015;33(1):124 e1-134.

20. Rossler J, Baselga E, Davila V, et al. Severe adverse events during sirolimus "off-label" therapy for vascular anomalies. Pediatr Blood Cancer. 2021: e28936.

21. Kahan BD, Napoli KL, Kelly PA, et al. Therapeutic drug monitoring of sirolimus: correlations with efficacy and toxicity. Clin Transplant. 2000;14(2): 97-109.

22. Mizuno T, Fukuda T, Emoto C, et al. Developmental pharmacokinetics of sirolimus: implications for precision dosing in neonates and infants with complicated vascular anomalies. Pediatr Blood Cancer. 2017;64(8):e26470.

23. Czechowicz JA, Long-Boyle JR, Rosbe KW, Mathes EF, Frieden IJ, Shimano KA. Sirolimus for management of complex vascular anomalies-a proposed dosing regimen for very young infants. Int J Pediatr Otorhinolaryngol. 2018;105:48-51.

24. Champion L, Stern M, Israel-Biet D, et al. Brief communication: sirolimus-associated pneumonitis: 24 cases in renal transplant recipients. Ann Intern Med. 2006;144(7):505-9.

25. Schena FP, Pascoe MD, Alberu J, et al. Conversion from calcineurin inhibitors to sirolimus maintenance therapy in renal allograft recipients: 24-month efficacy and safety results from the CONVERT trial. Transplantation. 2009;87(2): 233-42.

26. Rodriguez-Moreno A, Ridao N, Garcia-Ledesma P, et al. Sirolimus and everolimus induced pneumonitis in adult renal allograft recipients: experience in a center. Transplant Proc. 2009;41(6): 2163-5.

27. Garrean S, Massad MG, Tshibaka M, Hanhan Z, Caines AE, Benedetti E. Sirolimus-associated interstitial pneumonitis in solid organ transplant recipients. Clin Transplant. 2005;19(5):698-703.

28. Maschmeyer G, De Greef J, Mellinghoff SC, et al. Infections associated with immunotherapeutic and molecular targeted agents in hematology and oncology. A position paper by the European Conference on Infections in Leukemia (ECIL). Leukemia. 2019;33(4):844-62. 
29. Queisser A, Boon LM, Vikkula M. Etiology and genetics of congenital vascular lesions. Otolaryngol Clin N Am. 2018;51(1):41-53.

30. Nadal M, Giraudeau B, Tavernier E, Jonville-Bera AP, Lorette G, Maruani A. Efficacy and safety of mammalian target of rapamycin inhibitors in vascular anomalies: a systematic review. Acta Derm Venereol. 2016;96(4):448-52.

31. Bee J, Fuller S, Miller S, Johnson SR. Lung function response and side effects to rapamycin for lymphangioleiomyomatosis: a prospective national cohort study. Thorax. 2018;73(4):369-75.
32. Parker VER, Keppler-Noreuil KM, Faivre L, et al. Safety and efficacy of low-dose sirolimus in the PIK3CA-related overgrowth spectrum. Genet Med. 2019;21(5):1189-98.

33. Braun M, Young J, Reiner CS, et al. Low-dose oral sirolimus and the risk of menstrual-cycle disturbances and ovarian cysts: analysis of the randomized controlled SUISSE ADPKD trial. PLoS One. 2012;7(10):e45868.

34. Altomare DA, Khaled AR. Homeostasis and the importance for a balance between AKT/mTOR activity and intracellular signaling. Curr Med Chem. 2012;19(22):3748-62. 